\title{
The Response of Nitrogen Deposition to Methane Oxidation Availability and Microbial Enzyme Activities in Forest Soils
}

\author{
Inyoung Jang ${ }^{1}$, Hyoungmin Lee ${ }^{2}$, Hojeong Kang ${ }^{1 \dagger}$ \\ ${ }^{1}$ School of Civil and Environmental Engineering, Yonsei University, Seoul 120-749 Korea \\ ${ }^{2}$ Department of Environmental Science and Engineering, Ewha Womans University, Seoul 120-750 Korea
}

\begin{abstract}
Forest soils are often nitrogen-limited, and nitrogen input to forest soils can cause substantial changes in the structure and functions of a soil ecosystem. To determine the effects of nitrogen input on methane oxidation and the microbial enzyme activities, manipulation experiments were conducted using nitrogen addition to soil samples from Mt. Jumbong. Our findings suggested that the addition of nitrogen to the soil system of Mt. Jumbong did not affect the microbial enzyme activities. Conversely, the addition of nitrogen affected the rate of methane oxidation. Inorganic nitrogen in soils can inhibit methane oxidation via several mechanisms, such as substrate competition, toxic effects, and competition with other microbes, but the inhibitory effects are not always the same. In this research, seasonal changes were found to produce different inhibitory factors, and these different responses may be caused from differences in the methantrophic bacteria community structure.
\end{abstract}

Key words: Nitrogen addition, Methane oxidation, Enzyme activities, Forest soils

\section{Introduction}

Nitrogen is one of the limiting factors for many of the reactions within terrestrial ecosystems. Especially, forest soils are well known to be nitrogen deficient ecosystems. Therefore, nitrogen input into forest soils can cause many reaction changes. The input of nitrogen from atmospheric to terrestrial ecosystems has continuously increased over the past 300 years due to the increased use of fertilizers and fossil fuels. Nitrogen input to forest soils makes the availability of nitrogen much higher than in soils with no nitrogen addition; therefore, the primary production of plant is also stimulated, which alters the nitrogen cycle. In addition, extra nitrogen changes the $\mathrm{C} / \mathrm{N} / \mathrm{P}$ ratio in soils, which then causes changes in other nutrient cycles [1-3]. Other studies on the effects of nitrogen input on the microbial activities and community have been performed [4-7].

Nitrogen input to forest soils can also have an inhibitory effect on methane oxidation, which is an important function of forest soils. Methane is one of the most potent greenhouse gases, accounting for approximately $15 \%$ of the current greenhouse effects. One of the largest sinks for methane is soils, where methane can be oxidized by methanotrophic bacteria. The amount of methane oxidized by soil methanotrophic bacteria is estimated to be between 10 and $30 \mathrm{Tg} \mathrm{yr}^{-1}[8,9]$. Forest soils are well known to have a high ability for methane oxidation. Previous studies on methane oxidation by forest soils have shown the process is mainly controlled by the soil temperature [10-12] and moisture [11, 13-15], and by human activities, such as land use changes [16] and nitrogen input [17]. Nitrogen, especially in the form of ammonium ions, has drawn much attention due to its inhibitory effect on methane oxidation [18-20]. Recent studies have suggested that not only ammonium ions, but nitrate ions have inhibitory effects on methane oxidation. For example, $\mathrm{Xu}$ and Inubush [21] and Reay and Nedwell [22] showed a negative correlation between nitrate concentrations and the rates of methane oxidation in temperate forest soils.

In this research, a manipulation experiment was conducted with forest soils to determine the effects of nitrogen input on methane oxidation and the microbial enzyme activities.

\section{Materials and Methods}

\subsection{Soil Sampling}

These experiments were conducted in December 2007 and July 2008. Soil samples were collected from Mt. Jumbong $\left(38^{\circ} 02^{\prime} \mathrm{N}, 128^{\circ} 26^{\prime} \mathrm{E}\right)$, South Korea. Mt. Jumbong is a hard-wood (c) This is an Open Access article distributed under the terms of the Creative Commons Attribution Non-Commercial License (http://creativecommons. org/licenses/by-nc/3.0/) which permits unrestricted non-commercial use, distribution, and reproduction in any medium, provided the original work is properly cited.
Received April 25, 2010 Accepted May 03, 2010

${ }^{\dagger}$ Corresponding Author

E-mail: hj_kang@yonsei.ac.kr

Tel: +82-2-2123-5803 Fax: +82-2-364-5300 
forest located at the southern-most side of the Mt. Seorak national park, Kangwon Province. The site is included in a UNESCO Biosphere Reserve and designated as a Natural Forest Reserve by the Korea Forest Service. The soil is classified as sandy clay loam (sand: $49 \%$, silt: $24 \%$, clay: $27 \%$ ). Soil samples were collected at 3 different locations with different elevations (Table 1), with 2 replicates collected at each site to a depth of $5 \mathrm{~cm}$ from the soil surface, and the samples were sieved $(2 \mathrm{~mm})$ in the laboratory and then combined in equal amounts.

\subsection{Nitrogen Addition}

Thirty grams of the composite soil samples were placed into a $120 \mathrm{~mL}$ serum vial, with $12 \sim 150 \mu \mathrm{g}$ of $\mathrm{N}$ applied to the soil samples. The amount of $\mathrm{N}$ added was based on the estimation of $\mathrm{N}$ deposition reported by Park et al. [23] and Park and Lee [24]. Park et al. [23] estimated the rate of dry deposition using a simplified chemical model; whereas, Park and Lee [24] monitored the amounts of wet nitrogen deposition from 10 sites over South Korea. To determinate the response of methane oxidation and enzyme activities to nitrogen addition to the soil samples, 4 different concentrations of $\mathrm{NH}_{4} \mathrm{NO}_{3}$ were added to the soil samples (2.40, 4.74, 24.0 and $47.4 \mathrm{ng} \mathrm{g}^{-1}$ soil: ANN(1), ANA(1), ANN(10), ANA(10)). To remove the effects of other salts (i.e., $\mathrm{Na}^{+}, \mathrm{SO}_{4}^{2-}$ ) on methane oxidation and enzyme activities, separate treatments of $\mathrm{NaNO}_{3}$ were prepared (1.20 and $11.99 \mathrm{ng} \mathrm{g}^{-1}$ soil: $\mathrm{SN}(1)$ and $\mathrm{SN}(10))$ and $\left(\mathrm{NH}_{4}\right)_{2} \mathrm{SO}_{4}$ (2.37 and $23.69 \mathrm{ng} \mathrm{g}^{-1}$ soil: $\mathrm{AS}(1)$ and AS(10)). These soils were incubated for two weeks.

\subsection{Methane Fluxes}

After incubation for one day to allow for stabilization, the vials were sealed with a septum and injected with a high concentration of methane (300 ppmv). Gas sampling was conducted every day for two weeks using a gas tight syringe. The gas samples were analyzed in the laboratory using GC-FID (PORAPAK Q 80/ 100 column, the detector operated at $150^{\circ} \mathrm{C}$, carrier gas: $\mathrm{N}_{2}$ ). The methane oxidation rates were calculated using the following equation [25]:

$$
\mathrm{F}_{\mathrm{M}}=\frac{\delta \mathrm{C}_{\mathrm{CH} 4}}{\delta \mathrm{t}} \times \frac{\mathrm{V} \times \mathrm{M}_{\mathrm{CH} 4}}{\mathrm{~g} \mathrm{soil} \times \mathrm{V}_{\mathrm{mol}}}
$$

where $\mathrm{F}_{\mathrm{M}}$ is the flux of methane gas ( $\mu \mathrm{C} \mathrm{CH}_{4} \mathrm{~g}$ soil $^{-1} \mathrm{~min}^{-1}$ ); $\frac{\delta \mathrm{C}_{\mathrm{CH} 4}}{\delta \mathrm{t}}$ the rate of change in the methane concentration $\left(\mu \mathrm{mol} \mathrm{mol}^{-1}\right.$ $\left.\min ^{-1}\right)$ over time; $\mathrm{V}$ the chamber headspace volume $\left(\mathrm{m}^{3}\right) ; \mathrm{M}_{\mathrm{CH} 4}$ the molecular weight of methane $\left(16 \mathrm{~g} \mathrm{~mol}^{-1}\right)$ and $\mathrm{V}_{\mathrm{mol}}$ the volume of a mole of gas at a certain temperature $\left(\mathrm{m}^{3} \mathrm{~mol}^{-1}\right)$.

\subsection{Enzyme Activities in Soils}

The enzyme activities were measured at the end of the incubation period. Methylumbelliferyl (MUF)-substrates were used as model substrates for the soil enzymes. MUF- $\beta$-D-glucoside (MUF-G), MUF-N-acetylglucosaminide (MUF-N), MUF-phosphate (MUF-P) and MUF-sulfate (MUF-S) were used for B-glucosidase, $\mathrm{N}$-acetylglucosaminidase, phosphatase and arylsulfatase, respectively. Soil samples of $1.5 \mathrm{~g}$ were amended with $5 \mathrm{ml}$ of the substrate $(400 \mu \mathrm{mol})$. After 60 -min incubation at $20^{\circ} \mathrm{C}$, the fluorescence of the supernatant was determined using a TD-700 fluorometer at emission and excitation wavelengths of 450 and $330 \mathrm{~nm}$, respectively. For each sample, a calibration curve was prepared using $0 \sim 200 \mu \mathrm{mol}$ of the MUF-free acid to account for the quenching effect and soil absorption [26].

\subsection{Statistical Analysis}

To determine the effects of the addition of nitrogen and seasonal variations, the methane oxidation rates and activities were analyzed using a two-way ANOVA. Non-parametric correlation was used to determine the relationships between environmental factors and the methane oxidation rates.

\section{Results}

\subsection{Methane Oxidation Rates}

The methane oxidation rates varied from 11.29 to $16.23 \mathrm{ng}$ $\mathrm{g}^{-1}$ soil day ${ }^{1}$ (Fig. 1), and those during winter were significantly higher than those during summer $(p<0.001)$. The relative rates between the additions of nitrogen to the samples and controls were calculated (Fig. 2), with inhibitory rates from -2.05 to $18.89 \%$. Some samples, i.e. ANN(1) and ANN(10) in summer and AS(1) were stimulated by the addition of nitrogen. Especially, the rates of methane oxidation of $\mathrm{AS}(10), \mathrm{SN}(10), \mathrm{ANA}(1)$ and ANA(10) were significantly different from that of the control $(P<0.05)$. A correlation analysis between the amount of nitrogen added and the methane oxidation was conducted, from which the oxidation rates in winter showed a significant negative cor-

Table 1. Chemical properties of the study sites

\begin{tabular}{|c|c|c|c|}
\hline & Site 1 & Site 2 & Site 3 \\
\hline Altitude $(\mathrm{m})$ & 740 & 895 & 1066 \\
\hline Vegetation type & Acer pseudo-sieboldianum & Pinus koraiensis & Quercus mongolica \\
\hline Total carbon (\%) & $4.26(0.18)$ & $6.44(1.77)$ & $8.20(2.94)$ \\
\hline Total nitrogen $(\%)$ & $0.27(0.01)$ & $0.49(0.12)$ & $0.64(0.22)$ \\
\hline $\mathrm{C} / \mathrm{N}$ ratio & 15.7 & 13.1 & 12.8 \\
\hline Total phosphorus (\%) & $0.088(0.078)$ & $0.132(0.008)$ & $0.083(0.071)$ \\
\hline Extractable K (mg/kg) & $48.85(53.67)$ & $274.25(21.28)$ & $225.45(85.77)$ \\
\hline Extractable Ca (mg/kg) & $115.3(50.3)$ & $1650.5(983.6)$ & $1974.5(528.2)$ \\
\hline Extractable Mg (mg/kg) & $27.7(5.7)$ & $165.1(66.1)$ & $227.1(83.6)$ \\
\hline
\end{tabular}




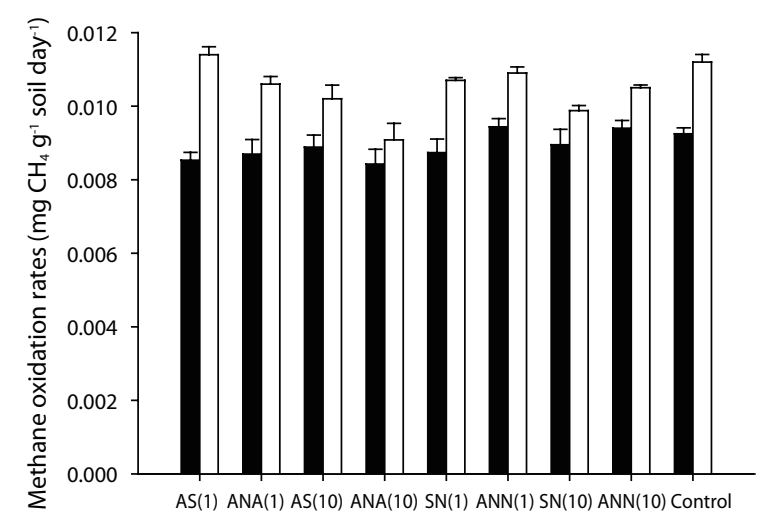

Fig. 1. Methane oxidation rates with different nitrogen treatments. The black bars represent the rates during summer, and the white bars those during winter. ANN(1), ANA(1), ANN(10) and ANA(10) represent 2.40, 4.74. 24.0 and $47.4 \mathrm{ng} \mathrm{NH}_{4} \mathrm{NO}_{3} \mathrm{~g}^{-1}$ soil, respectively; $\mathrm{SN}(1)$ and $\mathrm{SN}(10)$ are 1.20 and $11.99 \mathrm{ng} \mathrm{NaNO}_{3} \mathrm{~g}^{-1}$ soil; $\mathrm{AS}(1)$ and AS(10) show 2.37 and $23.69 \mathrm{ng}\left(\mathrm{NH}_{4}\right)_{2} \mathrm{SO}_{4} \mathrm{~g}^{-1}$ soil.

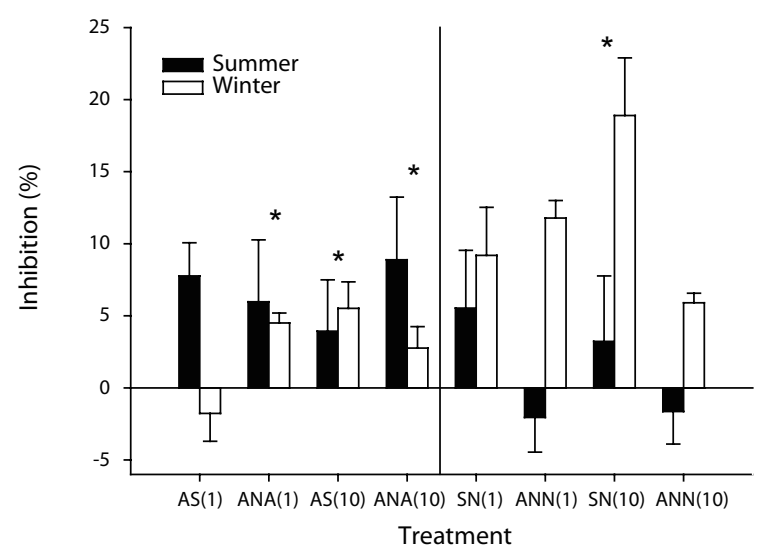

Fig. 2. The effects of inorganic ions on the $\mathrm{CH}_{4}$ oxidation rates. The relative rates were calculated as $\frac{\text { control-treatment }}{200} \times{ }^{*}$ denotes a significant difference between the treatment and control $(p<0.05)$. The black bars represent the oxidation rates during summer, and the white bars those during winter.

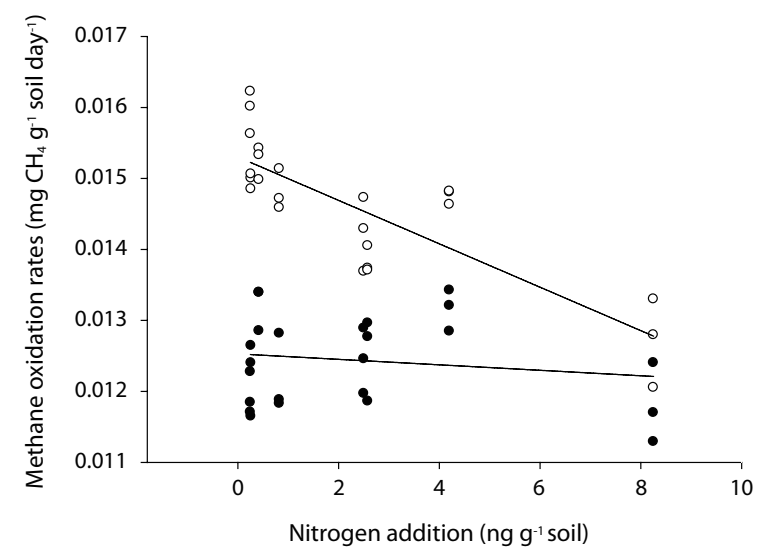

Fig. 3. The effects of nitrogen on methane oxidation rates during different seasons (black: summer, white: winter). relation with the amount of nitrogen added ( $\mathrm{r}=0.838, p=0.000$, $\mathrm{n}=30$ ). However, there was no significant relationship with the oxidation rates during summer (Fig. 3).

\subsection{Enzyme Activities}

The phosphatase and $\mathrm{N}$-acetylglucosaminidase activities exhibited the highest and lowest enzyme activities, respectively. The average values of $\beta$-glucosidase, phosphatase, arylsulfatase and N-acetylglucosaminisase during summer were 29.58, $53.12,22.93$ and $11.53 \mathrm{nmol} \mathrm{g}^{-1}$ soil $\mathrm{min}^{-1}$, respectively. In winter, the average values were $48.88,98.26,16.74$ and $10.83 \mathrm{nmol}$ $\mathrm{g}^{-1}$ soil $\mathrm{min}^{-1}$, respectively. The $\beta$-glucosidase, phosphatase and $\mathrm{N}$-acetylglucosaminidase activities during winter were significantly higher than those during summer ( $p<0.05$, Figs. $4 \mathrm{a}, \mathrm{b}$ and d), but the arylsulfatase activity was higher during summer than winter ( $p=0.001$, Fig. $4 \mathrm{c}$ ). There were no distinct differences between the treated samples and the control. Despite the correlation analysis, no effects of nitrogen addition were found with respect to the enzyme activities, but there was a positive correlation between the methane oxidation rates and enzyme activities (Table 2), with the exception of arylsulfatase.

Table 2. Correlation analyses of the enzyme activities and methane oxidation rates

\begin{tabular}{lccccc}
\hline & $\begin{array}{l}\mathrm{CH}_{4} \text { oxi- } \\
\text { dation }\end{array}$ & $\begin{array}{l}\boldsymbol{\beta} \text {-gluco- } \\
\text { sidase }\end{array}$ & $\begin{array}{l}\text { Phos- } \\
\text { phatase }\end{array}$ & Sulfatase & $\begin{array}{l}\text { N-acetyl } \\
\text { glucosa- } \\
\text { minidase }\end{array}$ \\
\hline $\mathrm{CH}_{4}$ oxidation & 1 & $0.551^{\mathrm{a}}$ & $.593^{\mathrm{a}}$ & $-0.426^{\mathrm{a}}$ & 0.024 \\
$\beta$-glucosidase & - & 1 & $.880^{\mathrm{a}}$ & -0.238 & $0.275^{\mathrm{b}}$ \\
Phosphatase & - & - & 1 & $-0.268^{\mathrm{b}}$ & $0.260^{\mathrm{b}}$ \\
$\begin{array}{l}\text { Sulfatase } \\
\begin{array}{l}\text { N-acetyl } \\
\text { glucosaminidase }\end{array}\end{array}$ & - & - & - & 1 & $0.467^{\mathrm{a}}$ \\
\hline
\end{tabular}

${ }^{\mathrm{a}} p<0.001$.

${ }^{\mathrm{b}} p<0.05$.

\section{Discussion}

The effects of the addition of nitrogen on the microbial activities and methane oxidation rates in forest soils were investigated. Due to nitrogen being a limiting factor, there has been extensive research on the topic of its impacts on forest ecosystems, including nitrogen addition and nutrient cycling, primary production and the microbial response [7, 10, 12]. However, no distinct differences have been observed in the enzyme activities between samples on the addition of nitrogen and the controls. The nitrogen cycle in forest soils is closely connected with other components, such as carbon and phosphorus. Especially, the $\mathrm{C} / \mathrm{N}$ ratio in forests soils is important in explaining the carbon and nitrogen cycles. According to Michel and Matzner [27], different responses were found on the addition of nitrogen in soils with various $\mathrm{C} / \mathrm{N}$ ratios. Forest soils with a low $\mathrm{C} / \mathrm{N}$ ratio showed no response on the addition of nitrogen, but higher $\mathrm{C} / \mathrm{N}$ ratios stimulated enzyme activities. From the experimental results of Michel and Matzner [27], the lower C/N ratio was 17.9, but the $\mathrm{C} / \mathrm{N}$ ratios at our sites varied from 12.8 to 15.7 , i.e. much lower. According to this comparison, it would appear that our forest 

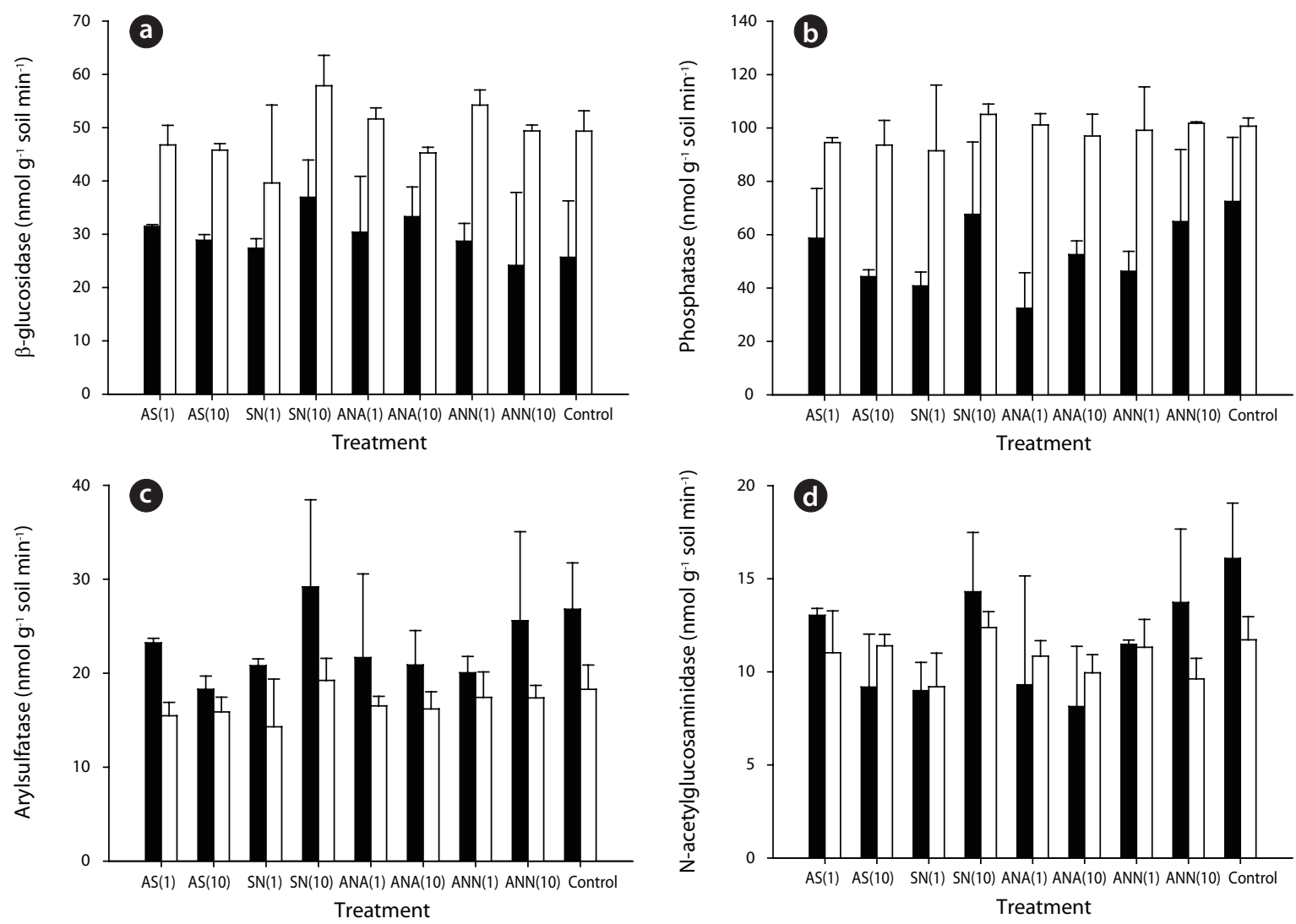

Fig. 4. Enzyme activities with different nitrogen treatments. a) $\beta$-glucosidase, b) phosphatase, c) arylsulfatase and d) $\mathrm{N}$-acetylglucosaminidase. The black bars represent the rates during summer, and the white bars those during winter. (ANN(1), ANA(1), ANN(10) and ANA(10) represent 2.40, 4.74, 24.0 and $47.4 \mathrm{ng} \mathrm{NH}_{4} \mathrm{NO}_{3} \mathrm{~g}^{-1}$ soil, respectively; $\mathrm{SN}(1)$ and $\mathrm{SN}(10)$ are 1.20 and $11.99 \mathrm{ng} \mathrm{NaNO}_{3} \mathrm{~g}^{-1}$ soil; AS(1) and AS(10) show 2.37 and $23.69 \mathrm{ng}\left(\mathrm{NH}_{4}\right)_{2} \mathrm{SO}_{4} \mathrm{~g}^{-1}$ soil).

ecosystem might be controlled by the availability of carbon.

However, inhibitory effects were observed on the methane oxidation rates on the addition of nitrogen, which varied from -2.05 to $18.89 \%$. Some samples exhibited negative values due to stimulation from the addition of nitrogen, but most samples showed the inhibitory effects. The effects of inorganic nitrogen on methane oxidation in forest soils have previously been investigated [17, 18, 20-22]. Methanotrophic bacteria, which can oxidize methane to methanol, have also shown the ability to oxidize ammonium ions [19]. Therefore, the existence of ammonium ions can inhibit methane oxidation, which has been reported in many studies [17, 21, 28]. Recently, there have been investigations on the inhibition of nitrate on methanotrophs, but the inhibitory mechanisms are yet to be revealed. There are some hypotheses aimed at better understanding this occurrence, with one being the possible toxicity of $\mathrm{NO}_{2}{ }_{2}^{-}$towards methanotrophic bacteria. According to Dunfield and Knowles [29], nitrite acted as a toxicant to methanotrophic bacteria. Nitrate can be reduced to nitrite due to anaerobic micro-sites in otherwise aerobic soil. In these spots, nitrate can be reduced to nitrite, which will affect methane oxidizers; another possibility is competition with other microbes. Since methanotrophic bacteria are heterotrophic, they are not subject to environmental factors [19], but other microbes are easily are affected by environmental factors, such as temperature, $\mathrm{pH}$ and nutrient availability. Therefore, the addition of nitrogen might stimulate other microbes, which can out- compete the methanotrophic bacteria and; thereby, inorganic nitrogen can inhibit methane oxidation.

The effects of nitrogen on methane oxidation were found to be seasonally different, with those during winter inhibited by the addition of nitrogen, but this effect was not shown during summer. These differences might come from the different community structures of methanotrophic bacteria. Therefore, the community structure of methanotrophic bacteria was analyzed using a DNA-based experiment. The results showed the community structures distinctly differed with season. Especially, the community structure during winter was significantly different than that during summer (Unpublished data). Therefore, the response to the addition of nitrogen can differ.

\section{Conclusions}

The addition of nitrogen at Mt. Jumbong did not affect the microbial enzyme activities. Since, the $\mathrm{C} / \mathrm{N}$ ratio in this area was found to be low, the addition of nitrogen exhibited little effect. Conversely, the addition of nitrogen affected the methane oxidation rates. Inorganic nitrogen in soils could inhibit the methane oxidation rate via several mechanisms, such as substrate competition, toxic effects and competition with other microbes. However, the inhibitory effects are not always the same. In our research, they differed between seasons. These different re- 
sponses might come from the differences in the methantrophic bacteria community structure.

\section{Acknowledgments}

This study was supported by funds from NRF (2009-0092795), KOSFE (F01-2008-000-10131-0), AEBRC, and Yonsei University endowed to H. Kang.

\section{References}

1. Aber JD, Nadelhoffer KJ, Steudler P, Melillo JM. Nitrogen saturation in northern forest ecosystems. BioScience 1989;39:378-386.

2. Mansson KF, Falkengren-Grerup U. The effect of nitrogen deposition on nitrification, carbon and nitrogen mineralisation and litter C:N ratios in oak (Quercus robur L.) forests. For. Ecol. Manage. 2003;179:455-467.

3. Kristensen HL, Gundersen P, Callesen I, Reinds GJ. Throughfall nitrogen deposition has different impacts on soil solution nitrate concentration in European coniferous and deciduous forests. Ecosystems 2004;7:180-192.

4. Nadelhoffer KJ, Emmett BA, Gundersen P, et al. Nitrogen deposition makes a minor contribution to carbon sequestration in temperate forests. Nature 1999;398:145-148.

5. Neff JC, Townsend AR, Gleixner G, Lehman SJ, Turnbull J, Bowman WD. Variable effects of nitrogen additions on the stability and turnover of soil carbon. Nature 2002;419:915-917.

6. DeForest JL, Zak DR, Pregitzer KS, Burton AJ. Atomspheric nitrate deposition, microbial community composition, and enzyme activity in northern hardwood forests. Soil Sci. Soc. Am. J. 2004;68:132-138.

7. Waldrop MP, Zak DR, Sinsabaugh RL. Microbial community response to nitrogen deposition in northern forest ecosystems. Soil Biol. Biochem. 2004;36:1443-1451.

8. Fung I. Three-dimensional model synthesis of the global methane cycle. J. Geophys. Res. 1991;96:13033-13065.

9. Lelieveld J, Crutzen PJ, Dentener FJ. Changing concentration, lifetime and climate forcing of atmospheric methane. Tellus B: Chem. Phys. Meteorol. 1998;50:128-150.

10. Crill PM. Seasonal patterns of methane uptake and carbon dioxide release by a temperate woodland soil. Global Biogeochem. Cycles 1991;5:319-334.

11. Whalen SC, Reeburgh WS. Moisture and temperature sensitivity of $\mathrm{CH}_{4}$ oxidation in boreal soils. Soil Biol. Biochem. 1996;28:12711281.

12. Savage K, Moore TR, Grill PM. Methane and carbon dioxide exchanges between the atmosphere and northern boreal forest soils. J. Geophys. Res. D: Atmos. 1997;102:29279-29288.

13. Koschorreck M, Conrad R. Oxidation of atmospheric methane in soil: measurements in the field, in soil cores and in soil samples. Global Biogeochem. Cycles 1993;7:109-121.

14. Castro MS, Melillo JM, Steudler PA, Chapman JW. Soil moisture as a predictor of methane uptake by temperate forest soils. Can. J. Forest Res. 1994;24:1805-1810.

15. Borken W, Xu YJ, Beese F. Conversion of hardwood forests to spruce and pine plantations strongly reduced soil methane sink in Germany. Global Change Biol. 2003;9:956-966.

16. Borken W, Brumme R, Xu YJ. Effects of prolonged soil drought on $\mathrm{CH}_{4}$ oxidation in a temperate spruce forest. J. Geophys. Res. D: Atmos. 2000;105:7079-7088.

17. Wang ZP, Ineson P. Methane oxidation in a temperate coniferous forest soil: Effects of inorganic N. Soil Biol. Biochem. 2003;35:427433.

18. Steudler PA, Bowden RD, Melillo JM, Aber JD. Influence of nitrogen fertilization on methane uptake in temperate forest soils. Nature 1989;341:314-316.

19. Hanson RS, Hanson TE. Methanotrophic bacteria. Microbiol. Rev. 1996;60:439-471.

20. Bradford MA, Wookey PA, Ineson P, Lappin-Scott HM. Controlling factors and effects of chronic nitrogen and sulphur deposition on methane oxidation in a temperate forest soil. Soil Biol. Biochem. 2001;33:93-102.

21. Xu X, Inubushi K. Effects of N sources and methane concentrations on methane uptake potential of a typical coniferous forest and its adjacent orchard soil. Biol. Fertility Soils 2004;40:215-221.

22. Reay DS, Nedwell DB. Methane oxidation in temperate soils: effects of inorganic N. Soil Biol. Biochem. 2004;36:2059-2065.

23. Park SU, Lee YH, Lee EH. Estimation of nitrogen dry deposition in South Korea. Atmos. Environ. 2002;36:4951-4964.

24. Park SU, Lee YH. Spatial distribution of wet deposition of nitrogen in South Korea. Atmos. Environ. 2002;36:619-628.

25. Lessard R, Rochette P, Topp E, Pattey E, Desjardins RL, Beaumont G. Methane and carbon dioxide fluxes from poorly drained adjacent cultivated and forest sites. Can. J. Soil Sci. 1994;74:139-146.

26. Kang H, Lee D. Changes of soil enzyme activities by simulated acid and nitrogen deposition. Chem. Ecol. 1998;14:123-131.

27. Michel K, Matzner E. Response of enzyme activities to nitrogen addition in forest floors of different C-to-N ratios. Biol. Fertility Soils 2003;38:102-109.

28. Bradford MA, Ineson P, Wookey PA, Lappin-Scott HM. The effects of acid nitrogen and acid sulphur deposition on $\mathrm{CH}_{4}$ oxidation in a forest soil: a laboratory study. Soil Biol. Biochem. 2001;33:16951702.

29. Dunfield P, Knowles R. Kinetics of inhibition of methane oxidation by nitrate, nitrite, and ammonium in a humisol. Appl. Environ. Microbiol. 1995;61:3129-3135. 